Raf. J. Sci.,Vol.27, No.4 /Special Issue for the Third Scientific Conference of Biology, pp.8-18, 2018

\title{
Investigation of some Carboxylic Acids and Phenolic Compounds of Ailanthus altissima Leaves and their its Effect on Italian Cupressus Seedlings Root Rot Fungi
}

\author{
* Fanar H. Al-Hashumi \\ Department of Horticulture / College of Agriculture and Forestry/ University of Mosul \\ **Anwer N. Al-Khero \\ Department of Forestry / College of Agriculture and Forestry/ University of Mosul \\ *** Ayad Ch. Al-daody \\ Department of Biology/College of Education for Girls/ University of Mosul \\ *E-mail: dr-fanarhashum@yahoo.com. \\ ***ayad chachaniraq@yahoo.com
}

(Received 1/4/2018 ; Accepted 1/11/2018)

\begin{abstract}
The study was carried out for separation and identification of some carboxylic acids such as Aspartic, Citric, Tartaric, Propionic, Ascorbic, Maleic and Fumaric, Adepic acid, as well as Phenol, Resorcinol, Hydroguinone, Quercetine, p-Hydroxybenzoic, Benzoic acid and Gallic acid from Alianthus altissima determined by High Performance Liquid Chromatography (HPLC). Moreover the major components of carboxylic acid were presented as Ascorbic acid (86.38\%). Also the phenolic compounds was studied and the results showed that P- Hydroxy benzoic acid (41.99\%) was the highest amount. Isolation results from Cupressus seedlings infected with root rot disease appearance of the fungus $F$. solani, F. oxysporum, F. chlamydosporium and Rhizoctonia solani, the isolation ratios was $41 \%$ as amaximum value for $F$. solani, then $F$. oxyspoum $(27 \%), F$. chlamydosporium (12\%) which was minimum value and Rhizoctonia solani (20\%).

Bioassay results of Ailanthus altissima leaves extract showed an increasing inhibition ratio of fungi growth with increasing leaves extract concentrations, F.oxysporum and F.chlamydosporium had the highest degree of growth inhibition (100) \% for the two fungus at (4\%) extracts concentrations, then followed by the fungus F.solani and Rhizoctonia solani were (84. $78,57) \%$ respectively and Rhizoctonia solani had the minimum inhibition.

The results of average fungus growth treated with several concentrations of Ailanthus leaves extracts with PDA media showed inhibition of growth with increasing extracts concentration, $F$. chlamydospoum had minimum mean growth $7 \mathrm{~mm}$ at $1 \%$ extract conc. whereas the two species of Fusarium showed maximum inhibition for average growth were zero values at $4 \%$ of extract conc. except Rhizoctonia solani which had a different value (19.67) $\mathrm{mm}$ at the same conc.
\end{abstract}

Keywords: Ailanthus altissima, Carboxylic acids, phenols, HPLC.

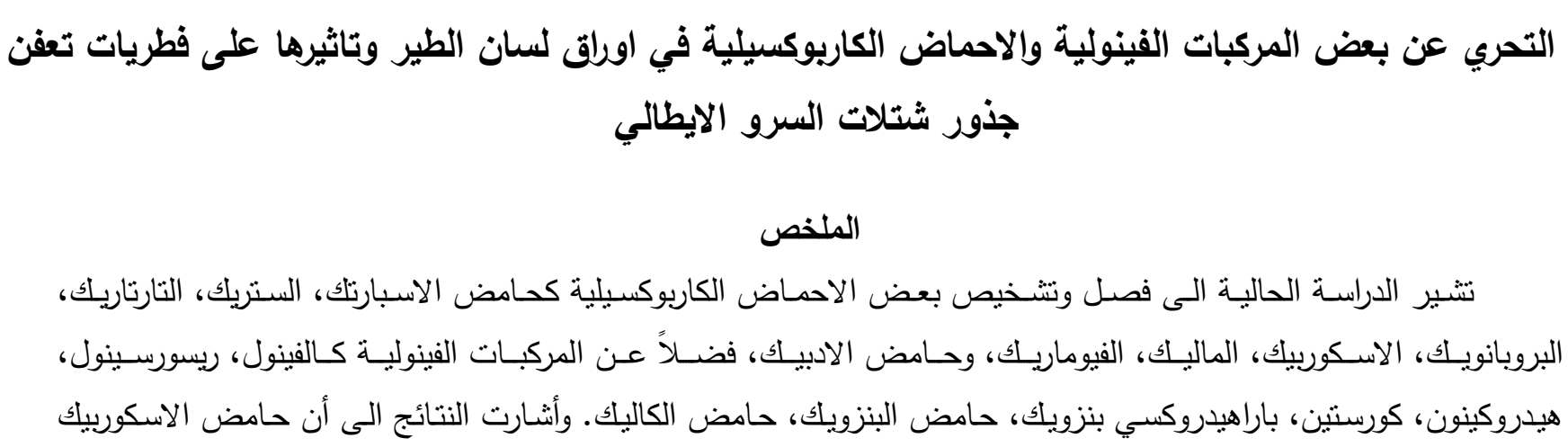


ظأعهر بأعلى نسية بلغت 41.99 \% 46.38 \% \% ، وكذلك نم دراسة المركبات الفينولية وأظهرت النتائج ان حامض بارهيدروكسي بنزويك ظهر

F. oxysporum و Fusarium solani أظهرت نتائج العزل من شتلات السرو المصابة بمرض تعفن الجذور فطريات

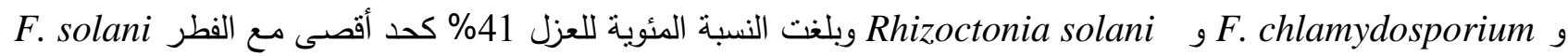

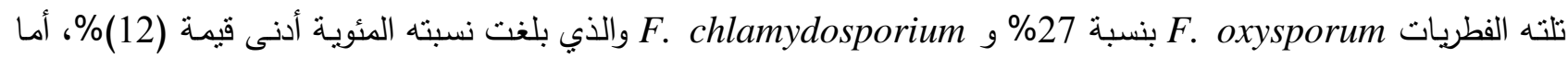
الفطر Rhizoctonia solani فكانت نسبة العزل 20\%، وتبين من نتائج الاختبار الحيوي لمستخلص أوراق لسـان الطير تأثر الفطريات مع زيادة التراكيز للمستخلص حيث أظهر الفطر Ailanthus altissima Rhizoctonia solani و F. solani تثبيط بتأثنير المستخلص بلغ 100\% عند التركيز 4\% من المستخلص تلته الفطريات حيث بلغت قيم تثيطها ( 84 و 57 و 87 )\% على النوالي، في حين أظهر الفطر Rhizoctonia solani أدنى نسبة تثبيط بتأثير المستخلص. كذلك أظهرت نتائج الاختبار الحيوي لمستخلص أوراق لسان الطير تتبيطاً معنوياً في منوسطات نمو الفطريات مع تركيز المستخلص حيث أظهر الفطر F. chlamydosporium ادنى ميوسط نمو تثبيط بتأثنر مستخلص الأوراق إذ بلغ 7 ملم عند التركيز 1\% من المستخلص، في حين أظهرت نوعي الفطر Fusarium أقصى تثبيطاً للنمو بلغت قيمته صفر عند التركيز 4. باسنثاء الفطر Rhizoctonia solani الذي كانت قيمة متوسط نموه 19.67 ملم عند نفس التركيز.

الكلمات الدالة: لسان الطير، الاحماض الكاربوكسيلية، الفينولات، HPLC.

\section{INTRODUCTION}

The plant Alianthus altissima commonly known as "there of heaven" or "smoke tree" belongs to the Family Simaroubeceae (Weekar et al., 2017). A.altissima is a fast- growing deciduous tree which is native to Asia. It was introduced in to Europe (1751) and to the United States (1784) into Eastern states by a Philadelphian gardener and in to western states by Chinese immigrants who used it for medicinal purpose. However, the tree was originally indigenous to china, but today it grows the wild and is cultivated in tropical and subtropical eastern Asia, Northern Europe and North America (Masteli and Jerkovi, 2002).

A.altissima is used in traditional medicine as a bitter aromatic drug in the treatment of colds and gastric diseases. The plant is known to have an antimalarial activity due to presence of active chemical constituents such as indole alkaloids, lipids, fatty acid, phenolic derivatives and volatile compounds from leaves (Raja et al., 2017). Monocarboxylic acids such as formic acid, acetic acid or propionic acid are fundamental materials in the chemical industry. The carboxylic acid are most widely used in the field of food and beverages as an acidulate and also in pharmaceutical and chemical industries. Carborylic acids are classified by the chemical structure R- COOH. In this acid form, they are fully hydrocarbon soluble. Only those organic acids with a carbon of five or less exhibit water solubility. However, an important characteristic of organic acids is that alkali metal salts of those compounds are readily souble in water and insoluble in hydrocarbon media (Sushil and Badu, 2014). Phenolic compounds are a group of secondary metabolites that are widespread in the plant kingdom. They are characterized by diverse chemical structure and numerous pharmacological properties. Their molecules contain two functional groups: a carboxyl group and a phenolic hydroxyl group (Carolina et al., 2014). Because of chemical structure, they can be divided into derivatives of cinnamic acid benzoic acid which differ from each other in the number of hydroxyl groups and the placement of methoxyl substitution, other pharmacological effects of 
phenolic acids are: antipyretic, antibacterial, anti-inflammatory, antipyretic, antifungal, anthelmintic, cholagogic and immune stimulant (Itoh, 2010).

Root rot fungi diseases is one of famous diseases and wide world pervasive which attach on tree roots cause high losses in nurseries (Agrios, 1987).

The importance of root rot diseases notice threw the many studies in world as compartment with another diseases (leaves, fruits and stems diseases) (Mohamed, 1994).

Cupressus seedlings root rot is an example of this kinds of diseases As the nurseries soil are unsterilized, the fungus, Macrophomina phaseolina, Fusarium and Rhizoctonia solani attached to Pinus brutia, Cupressus and Casuarina caused root rot disease at this seedlings (Mohammed, 1987). and the fungus F.equiset Corda sacca, Macrophomina phaseolina Tassi and seven isolations of Rhizoctonia solani Kuhn isolated from the roots of forest trees seedlings (Ali, 2007).

The aim of this study was the identification some carboxylic acid and phenolic compound by HPLC, and its effect on Italian cupressus seedlings root rot fungi.

\section{Taxonomic classification}

Kingdom: Plantae.

Phylum: $\quad$ Spermatophyta

Subphylum: Angiospermae

Class: $\quad$ Dicotyledonae.

Order: $\quad$ Rutales

Family: $\quad$ Simaroubaceae

Genus: $\quad$ Alianthus

Species: $\quad$ Alianthus altissima (NRCS, 2012).

\section{Plant Material}

\section{MATERIALS AND METHODS}

Leaves of A.altissima were collected from healthy trees (10 years) before flowering in ... 2017 at university of Mosul/Iraq, and were dried at room temperature $\left(25^{\circ} 2 \mathrm{C}^{\circ}\right)$ for one week, and kept in the dark until use.

\section{Soxhlet Extraction}

Soxhlet extraction was carried out with standard apparatus for (6-8) hrs. by using $150 \mathrm{~g}$ of dried leaves with $350 \mathrm{ml}$ of hexane to achieve de-fatted depending on the method of (Harborn, 1973).

\section{Extraction of Carboxylic Acids}

The leaves of A.altissima L. (150g) were re-extracted with $250 \mathrm{ml}$ of methanol by using magnetic stirrer for $72 \mathrm{hrs}$. at $60^{\circ}$. The mixture was filtered and completed to $10 \mathrm{ml}$ in a volumetric flask with methanol (Grand et al., 1988). the extract was filtered and evaporated under vacuum in a rotary evaporator at $65^{\circ}$ until $20 \mathrm{ml}$. The analysis was performed using HPLC (Shimadzu 20A), C18 column $(5 \mu \mathrm{m}, 150 \mathrm{mmx} 4.6 \mathrm{~mm})$ thermostatted at $30 \mathrm{C}^{\circ}$, the mobile phase was $40 \mathrm{mM} \mathrm{Na}_{2} \mathrm{SO}_{4}$. The $\mathrm{pH}$ was 2.68 adjusted with methanesulfonic acid with flow rate $1.0 \mathrm{ml} \mathrm{min}^{-1}$, UV at $210 \mathrm{~nm}$ and injection volume was $5 \mu \mathrm{L}$ (Dionex, 2004).

\section{Extraction of Phenolic Compounds}

After the extraction by hexane, the leaves of A.altissima $(150 \mathrm{~g})$ were re-extracted with $350 \mathrm{ml}$ of absolute ethanol by using soxhlet apparatus for $72 \mathrm{hrs}$. at $78 \mathrm{C}^{\circ}$. the extract was filtered and evaporated for acid hydrolysis, with $1 \mathrm{~N} \mathrm{HCL}$ for $1 \mathrm{hr}$ in both water at $100 \mathrm{C}^{\circ}$ and then the mixture was separated by using ethyl acetate when added to solution, two layers were shown, the ethyl acetate layer was kept for other analysis. The compounds that contain an ethyl acetate were identified by HPLC-Technique (Sahimadzu, LC, 2010 A/Japan). The column was C18 (4.6 × 240) $\mathrm{mm}$ at a flow- rate $1.5 \mathrm{ml} \mathrm{min}{ }^{-1}$, the mobile phase consisting of acetonitrite: water (80: 20) V/V, UV at $280 \mathrm{~nm}$ (Al-Tkey, 2012). Measurements were made in the laboratory of Baghdad university/ College of Education for Girls. 


\section{Identification of Compounds}

Analysis of carboxylic acids and phenolic compounds were identified by comparing the retention time of the samples with those of the known standards (Fig 1,3). The quantities of organic acids and phenolic compounds were estimated from the peak areas, injecting known amounts of the standards (Plein and Covdet, 2010).

\section{Isolation and Root Rot Fungi Identification}

Isolation from Italian cupressus seedlings which infected with root rot diseases depending by Agnihorti (1971) as well as diseases symptoms which appear at vegetative parts, samples of cupressus roots infected by root rot diseases transfered to forest diseases laboratory/ Forestry Dept. / College of Ari. and Forestry, the diseases samples were washed under running water for 30min., small pieces of cupressus infected root seedlings were cut especially the infected zones to small pieces at $0.5 \mathrm{~cm}$. then sterilized with $1 \%$ sodium hypochlorate for $3 \mathrm{~min}$., the species were removed from sterilization solution, washed with distilled water and dried between two sterile filter papers, then planted on sterilized petri dishes containing Potato Dextrose Agar ( PDA ) media supplied with antibiotic of streptomycin sulphate at $50 \mathrm{mg} / \mathrm{L}$ conc. to prevent the bacterial growth, these pieces distributed as avarege ( 4 pices /petri dish), incubated at $25-+2 \mathrm{c}$ for $5-7$ days

Purification of isolated fungi were made in test tubes containing Potato Dextrose slant agar as a nutrient media as we shall use it in subsequent experiments.

Fungi identification till to the genus level was made depending on the keys of (Barnett and Hunter, 2006) then to species depending on the keys of (Booth,1971) then isolation ratio were calculated.

\section{Bioassay of Ailanthus Extract}

Alcoholic extract of Ailanthus leaves with concentrations $(1 \%, 2 \%, 4 \%)$ were obtained from stock solution which contain phenolic compounds depending on Alyahya ( 2003) method, DMSO (Dimethoxysulphorside) as a solvent for dry extract of Ailanthus leaves, this conc. were added to sterile petri dishes and mixed with sterile PDA, in petri dishes at $5.5 \mathrm{~cm}$, Inoculation of isolated fungi were made on petri dishes (5.5 cm Dim.), disk of isolated fungi $(4 \mathrm{~mm}$. Dim.) which was taken from colony edge that modern growth, three replication for each concentration of extract were made, Results calculated by measuring two mean of orthogonal diameters for fungi growth (Alyahya, 2003 ).

\section{Identification of carboxylic acids}

\section{RESULTS AND DISCUSSION}

The $\mathrm{pH}$ of mobile phase and temperature are crucial parameters. The most suitable mobile phase used for separation of carboxylic acids are aqueous water, $\mathrm{pH}$ was adjusted 2.68 value with hydrochloric acid at temperature $30 \mathrm{C}^{\circ}$, therefore many carboxylic acids identified in A.altissima (Table 1) and Fig. (2).

An example of the chromatogram $\left(\mathrm{R}_{\mathrm{t}}\right)$ of the organic acids standards is given in (Table 1$)$. Many carboxylic acids could be separated in less than 14 minutes. Among the organic acids, Ascorbic acid showed the highest value followed by citric, Aspartic, and Maleic acids.

The individual and total levels of carboxylic acids in Ailanthus leaves may change according to the age of tree and the variety.

In conclusion, this methods is suitable for the determination of carboxylic acids in Ailanthus leaves. They can be determined in low concentrations with a great sensitivity. The procedure of organic acids extracts is simple and rapid These results were in agreement with the findings of (Pindla et al., 2012) and (Meinhart et al., 2012). 
Table 1: Chemical composition of carboxylic acids for A.altissima using HPLC technique

\begin{tabular}{|c|c|c|c|}
\hline $\begin{array}{c}\text { Carboxylic acids } \\
\text { compounds }\end{array}$ & $\begin{array}{c}\text { Standared } \\
\mathbf{R}_{\mathbf{t}}(\mathbf{m i n})\end{array}$ & $\begin{array}{c}\text { Extract Components } \mathbf{R}_{\mathbf{t}} \\
(\mathbf{m i n} .)\end{array}$ & Area\% \\
\hline Aspartic acid & 3.12 & 3.12 & 0.841 \\
\hline Citric acid & 3.60 & 3.32 & 0.939 \\
\hline Tartaric acid & 4.24 & 4.02 & 0.202 \\
\hline Propionic acid & 5.44 & 5.51 & 0.082 \\
\hline Ascorbic acid & 6.55 & 6.16 & 86.383 \\
\hline Maleic acid & 9.77 & 9.70 & 0.386 \\
\hline Fumaric acid & 12.37 & 12.09 & 0.044 \\
\hline Adepic acid & 13.57 & $\mathrm{~N} / \mathrm{D}$ & $\mathrm{N} / \mathrm{D}$ \\
\hline
\end{tabular}

\section{N/D: Not detected.}

$\mathrm{mV}$

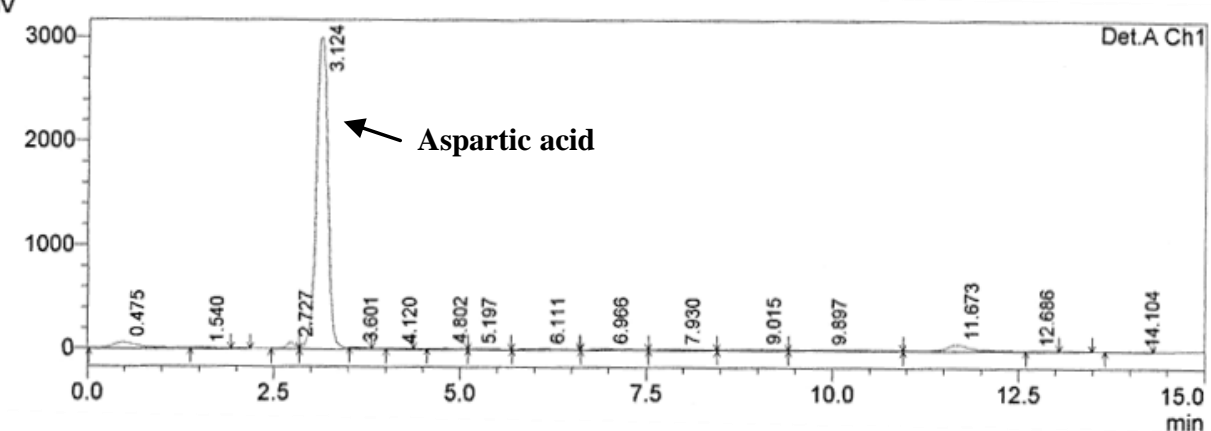

$\mathrm{mV}$

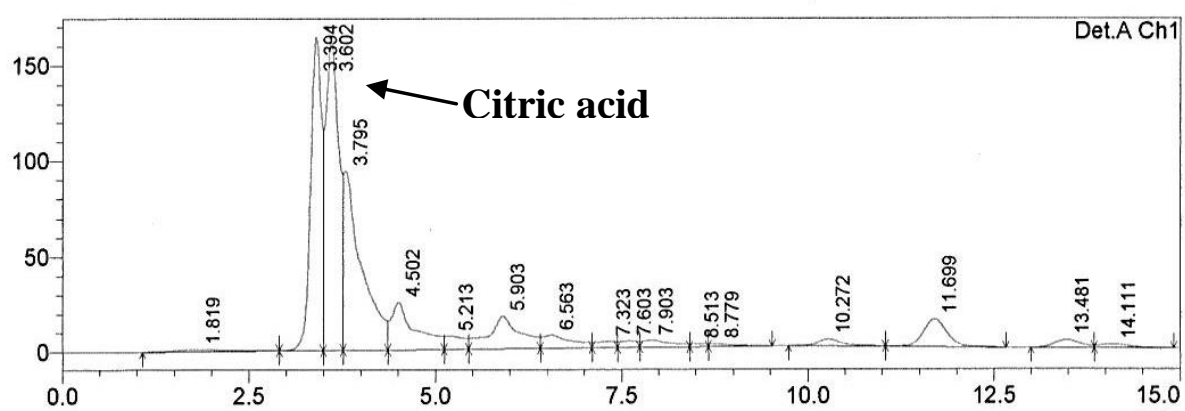

$\mathrm{mV}$
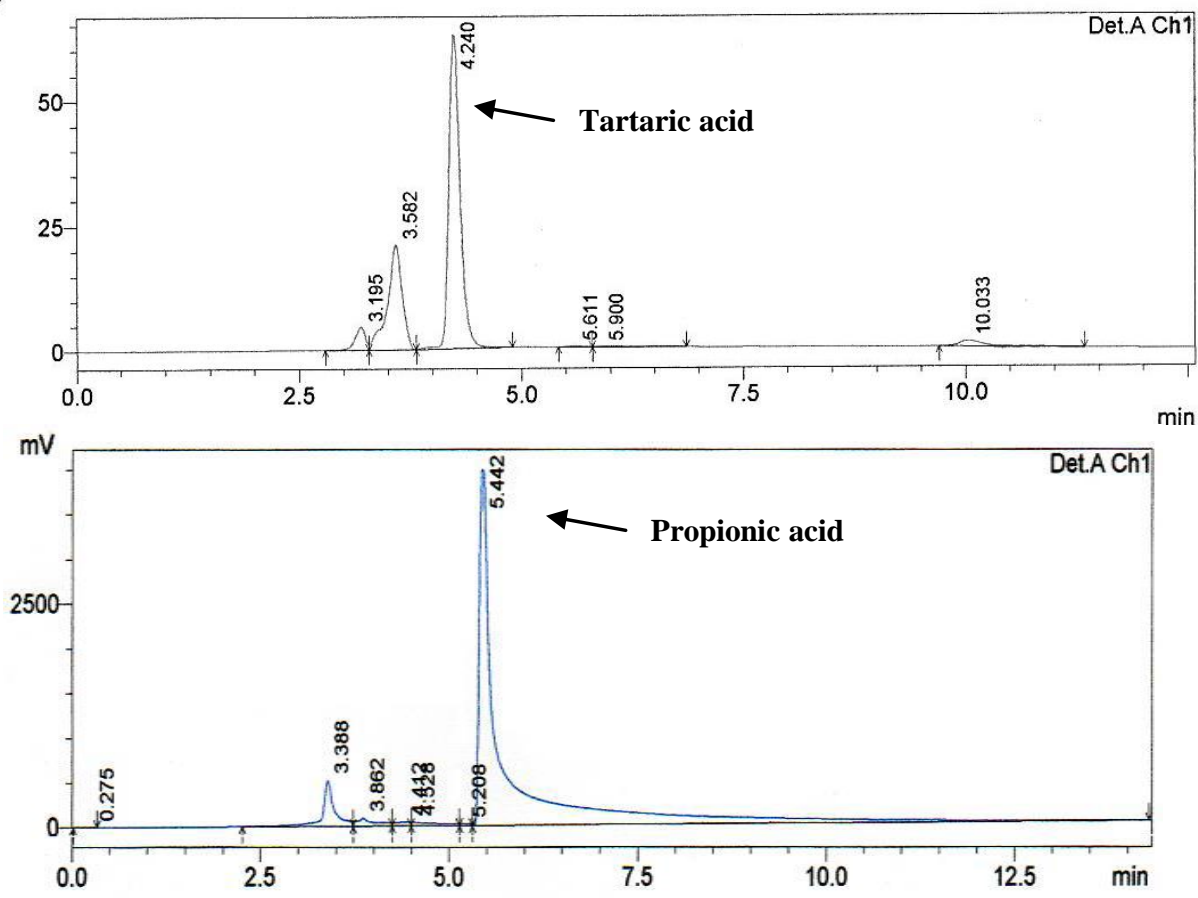
Fanar H. Al-Hashumi et al.

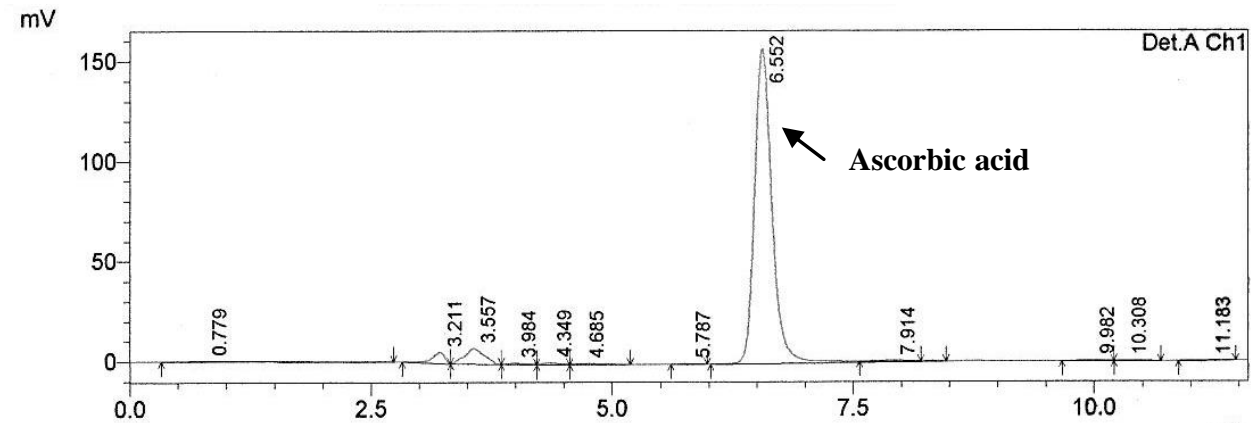

$m V$

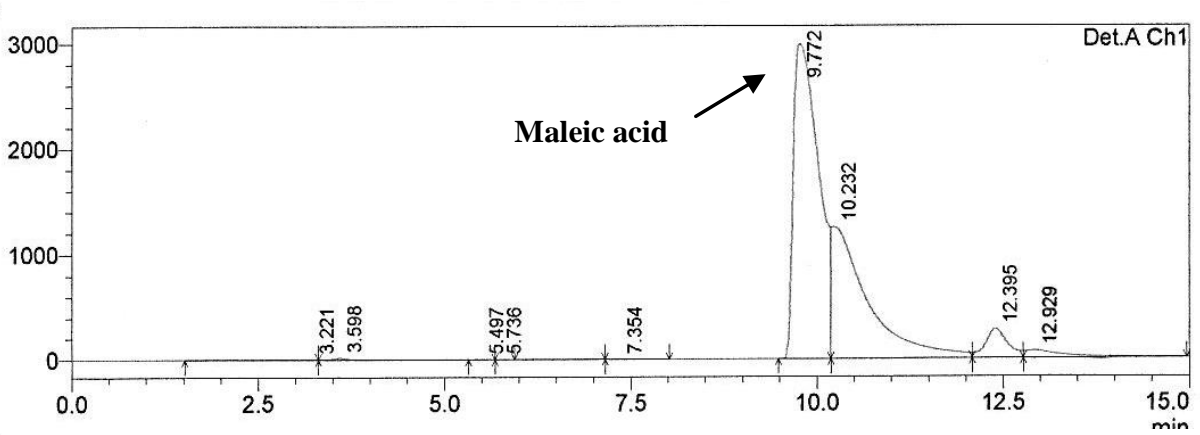

$\mathrm{mV}$

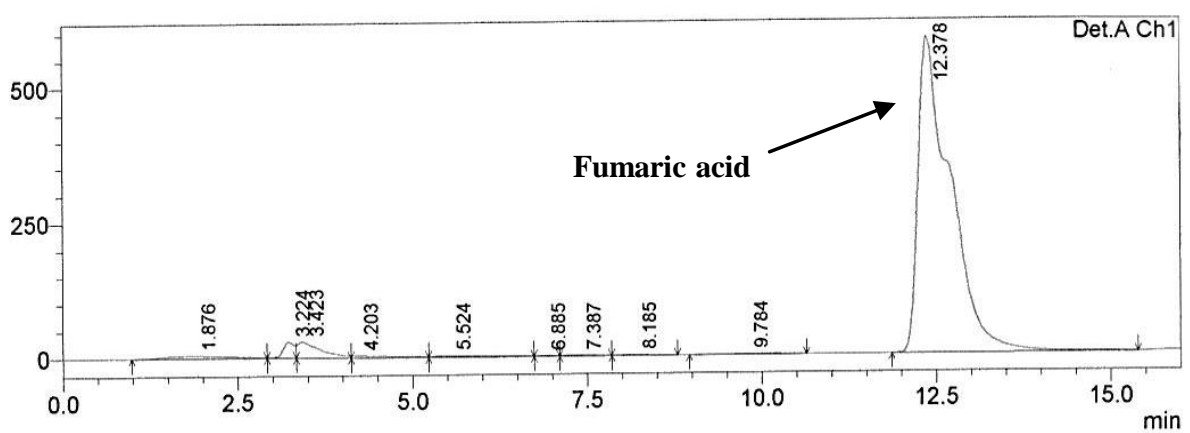

$\mathrm{mV}$

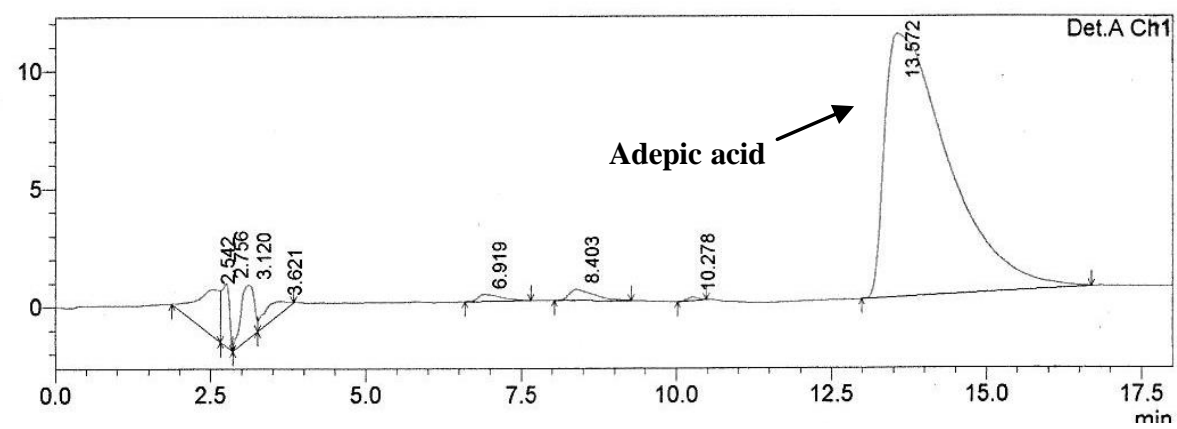

Fig. 1: HPLC chromatograms standards of carboxylic acid in Alianthus altissima

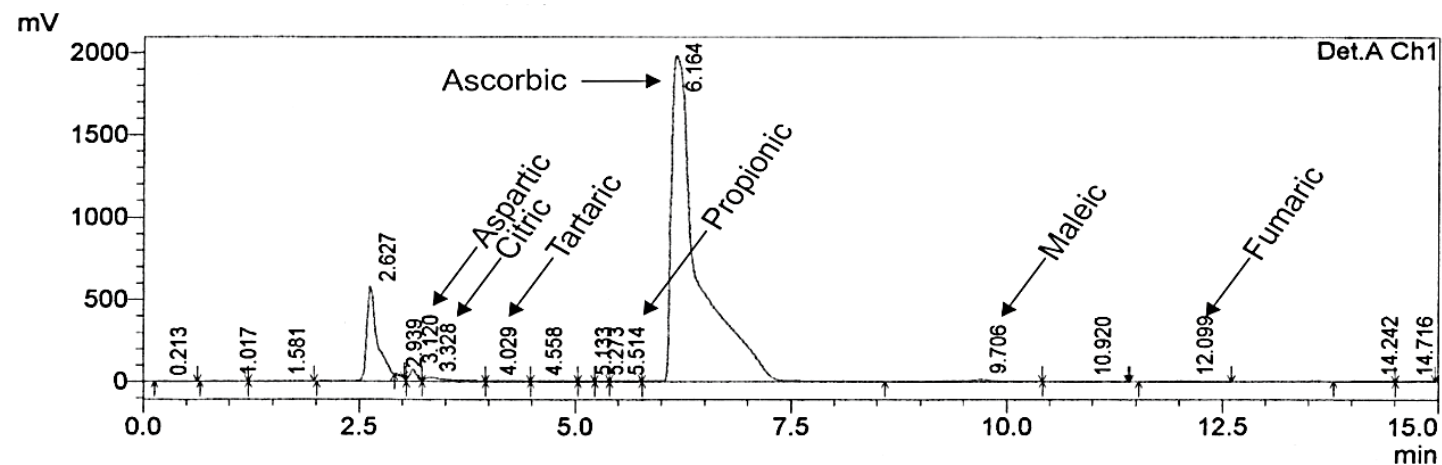

Fig. 2: HPLC Chromatograms of carboxylic acid in Ainathus altissima 


\section{Identification of Phenolic Compounds}

Previous studies have reported abundant Phenolic compounds in A.altimissa, such as (Rutin, Quercetin, Luteolin, Apigenia, Gallic acid, Chlorogenic acid, Epicatechia (Ferdaous et al., 2013). Phenolic compounds play an important role for normal growth in plant development, as well as defense against infection and injury, the presence of phenolics in injured plants may have an important effect on oxidative stability and microbial safety 25* (Plein and Cevdet, 2010), (Table 2) and Fig. (4) showed the maximum quantities (\%) and retention time Rt (min) of 6 standard and sample of A.altissima identified in ethanolic extract by HPLC- Technique.

All phenolic compounds were identified according to their retention time and spectral characteristics against those of standards. Results confirm a variation in phenolic content of plant extracts, the highest amount of P-hydroxybenzoic Gallic acid, Quercetin appeared in extract (Shakir et al., 2018) showed that the A.altissima leaves contain many phenolic compounds such as gallic acid, Quercetin, Rutin, chlorogenic acid, Luteolin, And a result of (Raja et al., 2017) who demonstrated that the quantitiative analysis showed the presence of callic acid, coumarin, Quercetin in A.altissima leaves in unsound quantities.

Table 2: Chemical composition of phenolic compounds for A.altissima using HPLC Technique

\begin{tabular}{|c|c|c|c|}
\hline Phenolic compounds & Standard $\mathbf{R}_{\mathbf{t}}(\mathbf{m i n})$ & $\begin{array}{c}\text { Extract Components } \\
\mathbf{R}_{\mathbf{t}}(\mathbf{m i n} .)\end{array}$ & Area\% \\
\hline Phenol & 2.37 & N/D & N/D \\
\hline Resorcinol & 2.72 & 2.67 & 1.648 \\
\hline Hydroquinone & 2.83 & 2.98 & 3.767 \\
\hline Quercetin & 3.02 & 3.13 & 9.864 \\
\hline P-Hydroxybenzoic & 3.20 & 3.32 & 41.993 \\
\hline Benzoic acid & 3.64 & 3.84 & 5.234 \\
\hline Gallic acid & 4.24 & 4.76 & 22.922 \\
\hline
\end{tabular}

N/D: Not detected

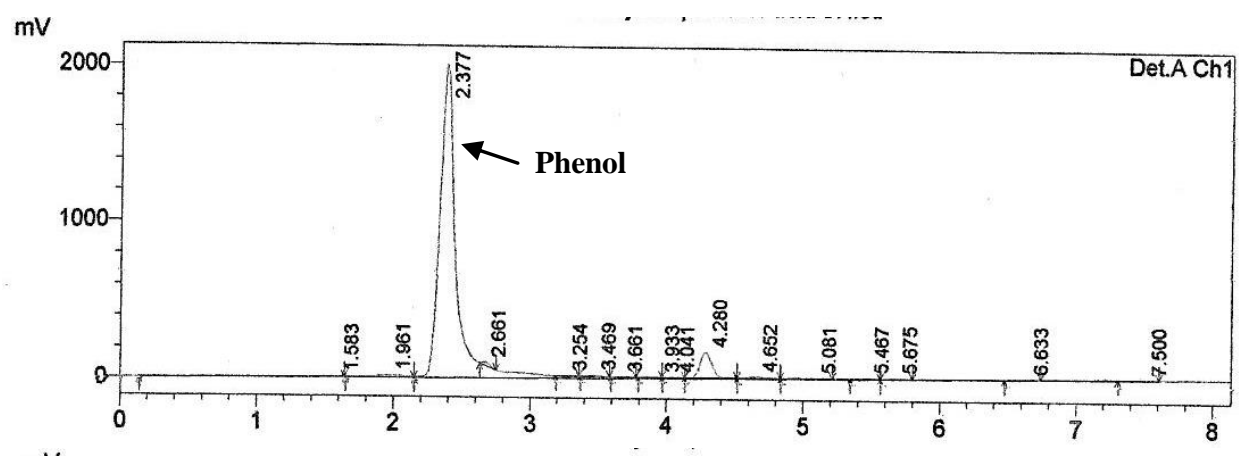

$m V$

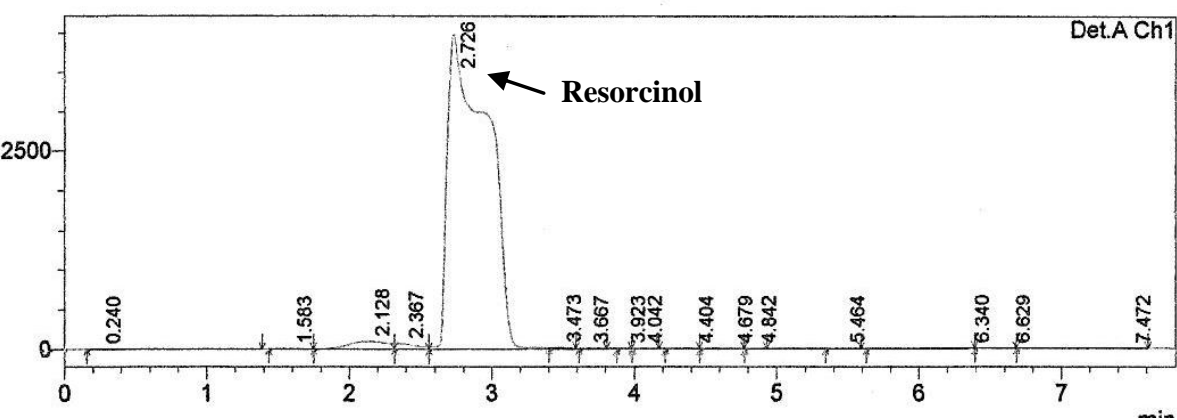


Fanar H. Al-Hashumi et al.
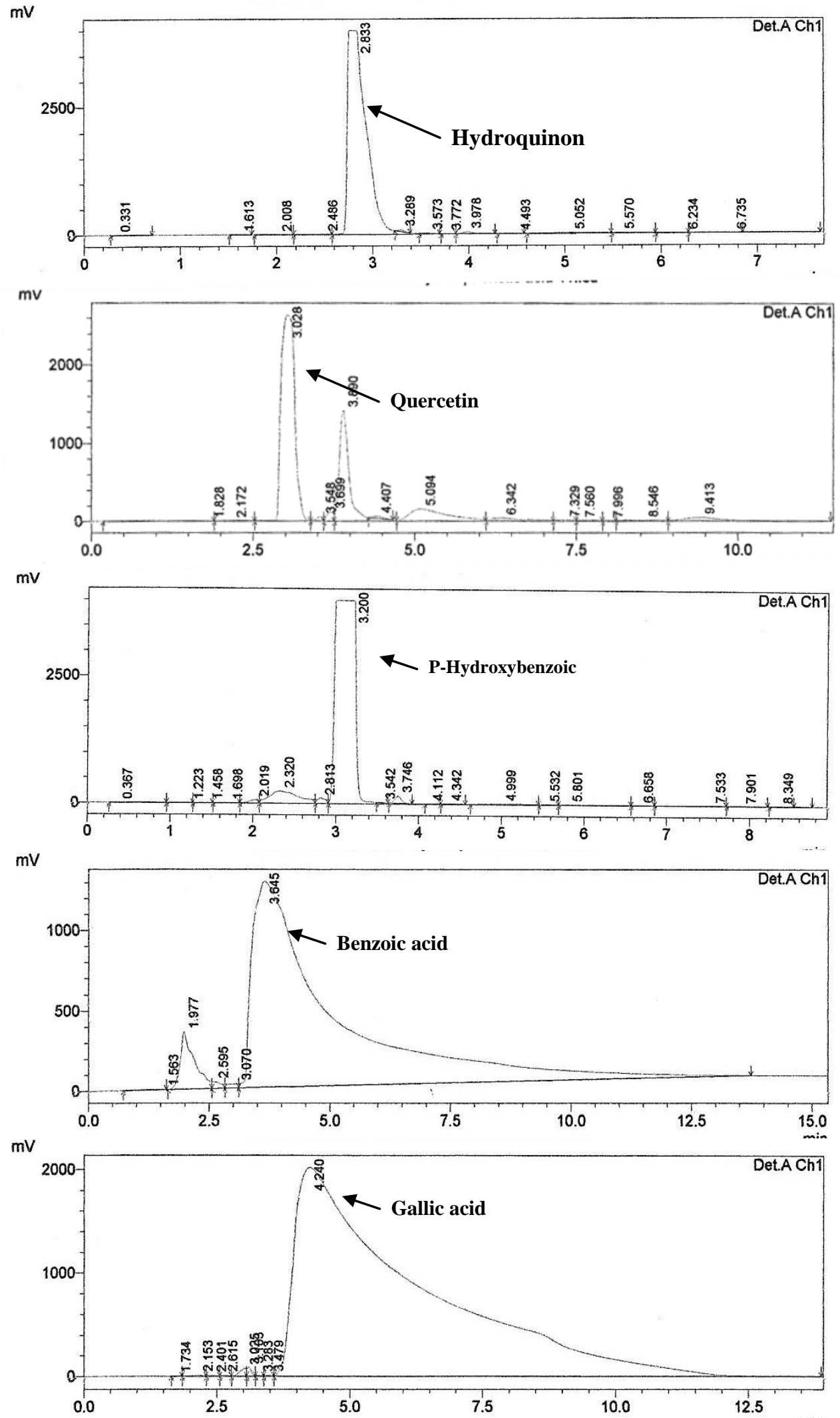

Fig. 3: HPLC chromatograms standards of phenolicsin Alianthus altissim 


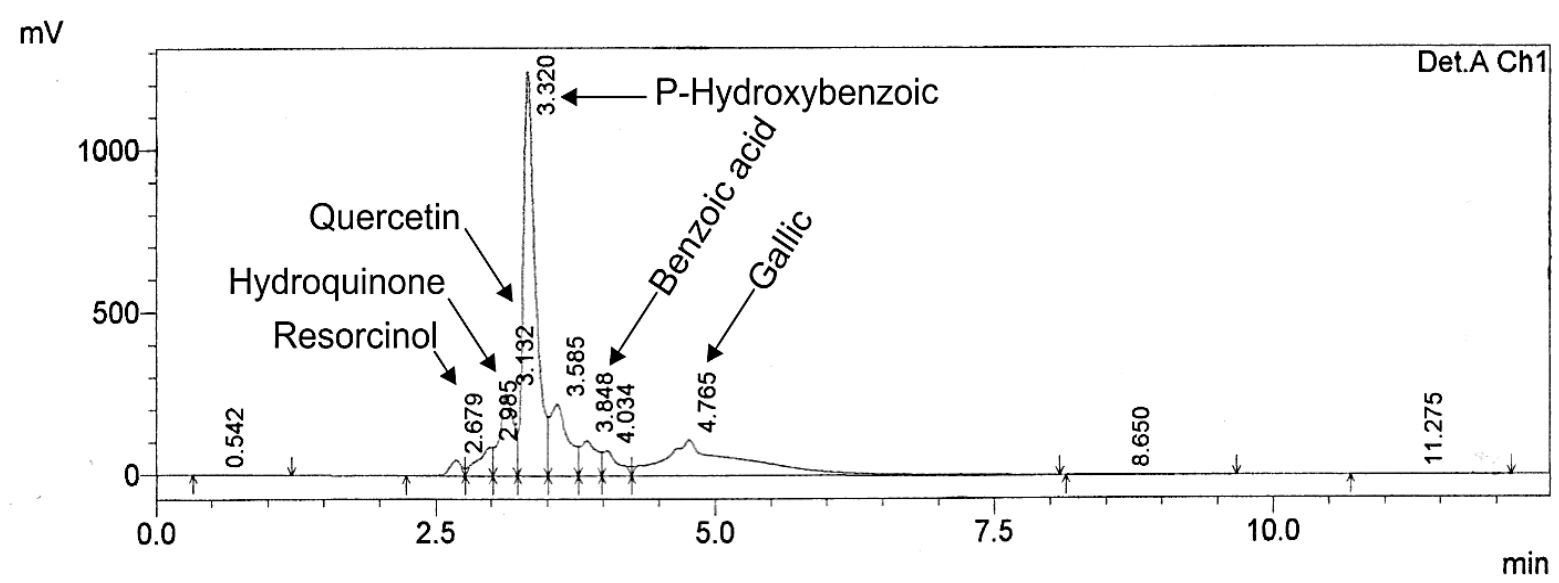

Fig. 4: HPLC chromatograms of phenolics in Ailanthus altissim.

\section{Isolation and Root Rot Fungi Identification:}

Isolation results from infected cupressus seedling by root rot disease showed appearance of the fungus $F$. solani, F. oxysproum, $F$. chlamydosporium and Rhizoctonia solani in different ratios (Table 3 ), the isolation ratios were $41 \%$ a maximum value for $F$. solani, then $F$. oxyspoum (27\%), F. chlamydosporium (12\%) which was minimum value and Rhizoctonia solani (20\%) .

Identification of fungi were according to universal classification keys to genus level (Barnett and Hunter, 2006) and to species level (Booth, 1971).

Table 3: Fungi isolation ratio from Italian Cupressus seedling infected by root rot diseases root

\begin{tabular}{|l|c|}
\hline \multicolumn{1}{|c|}{ Fungi } & \% Isolation \\
\hline Rhizoctonia solani & 20 \\
\hline F, solani & 41 \\
\hline F. oxysporum & 27 \\
\hline F.chlamydosporium & 12 \\
\hline
\end{tabular}

\section{Bioassay of Ailanthus Leaves Extract}

Average growth inhibition ratio calculation:

The results of bioassay for Ailanthus altissima leaves extract showed (Table 4) It was increasing in inhibition ratio of fungi growth with increasing of leaves extract concentrations, F.oxysporum and F.chlamydosporium had the highest degrees of growth inhibition (100) \% for the two fungus at (4\%) extracts concentrations, then followed by the fungus F.solani and Rhizoctonia $s p$. were $(84,78,57) \%$ respectively and Rhizoctonia solani. had minimum of inhibition.

Ethanolic leaves extract was anti fungal due to the glycoside compound and phenolic compounds which was anti fungus, the results of identification for extracts compounds by High Performace Liquid Chromotography, previous results were supported with (Ratha et al., 2003) about their using the ethanol extracts of Ailanthus altissima leaves for stopping the growth of fungus Aspargillus niger, Penicillium, Aspargillus flavus, Aspargillus fumigant. 
Table 4: Bioassay of different concentrations of Ailanthus leaves extracts and its affect on growth inhibition ratio of Italian Cupressus seedlings root rot fungi

\begin{tabular}{|l|c|c|c|c|}
\hline \multirow{2}{*}{$\begin{array}{c}\text { Extracts } \\
\text { Concentration } \\
\text { Fungi }\end{array}$} & Cont. & $\mathbf{1 \%}$ & $\mathbf{2 \%}$ & $\mathbf{4 \%}$ \\
\cline { 2 - 5 } & \multicolumn{5}{|c|}{ Growth inhibition ratio } \\
\hline F.oxysporym & $0 \mathrm{f}$ & $28.33 \mathrm{de}$ & $42 \mathrm{bcd}$ & $100 \mathrm{a}$ \\
\hline F.chlamydospoium & $0 \mathrm{f}$ & $31.67 \mathrm{cde}$ & $39.67 \mathrm{fcd}$ & $100 \mathrm{a}$ \\
\hline F.solani & $0 \mathrm{f}$ & $16.67 \mathrm{ef}$ & $54.33 \mathrm{~b}$ & $84.78 \mathrm{a}$ \\
\hline Rhizoctonia solani & $0 \mathrm{f}$ & $0 \mathrm{f}$ & $51 \mathrm{~b}$ & $57 \mathrm{~b}$ \\
\hline
\end{tabular}

\section{Diameter Growth Average of Isolated Fungi Calculation}

The results of average fungus growth treated with several concentrations of ailanthus leaves extracts with PDA media showed inhibition growth (Table 5) with increasing of extracts concentration, $F$. chlamydospoum had minimum mean growth $7 \mathrm{~mm}$ at $1 \%$ extract conc. whereas the two species of Fusarium showed maximum inhibition for average growth (zero values at $4 \%$ ) of extract conc. except Rhizoctonia solani whch had different value (19.67) $\mathrm{mm}$ at the same conc.

As the results followed we can used Ailanthus alcohol extract as natural material in control the root rot disease of cupressus seedlings especially the fungus Fusarium species in $4 \%$ conc, of ailanthus leaves extracts.

Table 5: Bioassay of different concentrations of Ailanthus leaves extracts and its affect on diameter growth averages of Italian cupressus seedlings root rot fungi

\begin{tabular}{|c|c|c|c|c|}
\hline \multirow{2}{*}{$\begin{array}{c}\text { Extract concentration } \\
\text { Fungi }\end{array}$} & Cont. & $1 \%$ & $2 \%$ & $4 \%$ \\
\hline & \multicolumn{4}{|c|}{ Diameters growth averages (mm) } \\
\hline F.oxysporym & 16 de & $15,67 \mathrm{de}$ & $11,33 \mathrm{ef}$ & $0 \mathrm{f}$ \\
\hline F.chlamydospoium & $10,33 \mathrm{ef}$ & $7 \mathrm{e}$ & $6 \mathrm{f}$ & $0 \mathrm{f}$ \\
\hline F.solani & $55 \mathrm{a}$ & $45,67 \mathrm{~b}$ & $25,33 \mathrm{f}$ & $8 \mathrm{f}$ \\
\hline Rhizoctonia solani & $43,67 \mathrm{~b}$ & $43 \mathrm{~b}$ & $22,67 \mathrm{~cd}$ & $19,67 \mathrm{~cd}$ \\
\hline
\end{tabular}

\section{REFERENCE}

Agnihorti, V.P. (1971). Effects of certain fungi toxicants viability and pathogenicity of sclerotia of waitea cercinata. Phytopathology. Z.,70, 71-80.

Agrios, G.N. (1987). "Plant Pathology". $3^{\text {rd }}$ ed, Copy right, Academic Press. 1451p.

AL- Tkey, T. (2012). Secondary chemical components and some anatomical properties of tree trunks of Melia azedarach L. Ph.D. thesis Forestry/ Wood Science, College of Agriculture and Forestry, University of Mosul, pp. 60-62.

Ali, R.M.S. (2007). Damping off and root rot of forest seedlings in Sulymania reign and its control. Msc. College of Agriculture. University of Sulymania, pp. 54-55.

Alyahya, S.A. (2003). Importance of natural plant extracts in control of fungi casual for plants diseases. Msc theses, Almalik esuod Univ. Suodia Arabiaq Kingdum, 146p.

Barnett, H.L.; Hunter, B.B. (2006). "Illusrated Genera of Imperfect Fungi". Burgess Publishing Company. $241 \mathrm{p}$.

Grand, A.; Verpoort, R.; Liowndoryram, P.A.; Opussel, J.L. (1988). Anti-infections phytotherapies of the II. Antimicrobial activity of 33 species. 
Booth, C. (1971) "Fusarium Guide to the Identification of the Majer Species". Commonwealth Mycology Institute, Ferry Lane, Kew, Surry, England.

Carolina, F.; Gloria, M.; Pablo, J.; Robert, P. (2014). Comparison of the total phenolic content, total anthocyanin content and antioxidant activity of polyphenol- rich fruits grown in chile. Cien. Inv. Agr. 41(1), 49-60.

Dionex (2004). Acleaim organic acid (OA) HPLC column. www.dionex.com.

Ferdaous, A.; Hassen, H.; casabianca', I.; Hosni, K. (2013). Phytochemicals, antioxidant, antimicrobial and phytotoxic activities of Ailnathus altissima (Mill) swingle leaves. South African J. Bot., 876, 164- 174.

Harborne, J.B. (1973). "Phytochevnical Methods: A Guide to Modern Technique of Plant Analysis. Isted". Cox and Wyman, London. pp. 52-73.

Itoh, A. (2010). Hepatoprotective effect of syringic acid and vanillic acid on CCI4 induced Liver injury. Biol. Pharm. Bull. 33, 983.

Masteli, J.; Jerkovi, I. (2002). Constituents from the leaves of young and old Ainathus altissima (Mill.) swingle tree. Croatical Chemical Acta, 75(1), 189- 197.

Meinhart, A.D.; Filho, J.; Godogy, H.I. (2012). Validation of a HPLC method for simultaneosus determination of main organic acids in fruits and Juice: Food Chem. 135, 150- 154.

Mohamed, N.Y. (1994). Complete control of damping off and root rot of sugar beet. Msc. College of Agriculture and forestry. University of Mosul, pp. 75-77.

Mohammed, A.N. (1987). Studies on Pinus bruta, Cupressus and Casuarina root rot disease in Ninavah and Hammam al aleel nurseries, Msc. degree. College of Agri. and Forestry, Mosul University, pp. 80-82.

NRCS, Natureal Resource Conservation Service, (2012). USA. Dept. of Agriculture, plants. Usda. Gov/corel profile, Symbol = AIAL, 13- 4.

Pindla, J.; Duenas, M.; Carvalho, A.; Santos, C. (2012). Antioxidant activity, ascorbic, phenolic compounds and sugars of wild and commercial Tuberaria Lignosa. Food Chem., 135, 10281035 .

Plein, E.; Cocevdet, N. (2010). Determination of organic acids in olive fruit by HPLC. Czech. J. Food. Sci, 28(3), 202- 205.

Raja, W.Y.; Zulfiqar, A.; Ishtiyag, A.C. (2017). Pharmacognostic and phytochemical characteristics of Alianthus altissima (Mill.) swingle stem on root bark: A comparative study. Pharmacogn, J., 9(5), 668-673.

Ratha, R.R.1.; Shamkuwar, P.B.; Pawar, D.P. (2003). Antifungal study of Ailanthus excelsa leaves. J. Chem. Pharma. Res., 5(6),152-154.

Skakir, U.; Farzana, G.; Maria, K.; Hameda, B. (2018). Antifungal and phytochemical screening of selected medicinal plant of malamjaba. Swat. Pakistan, the Pharma Innovation J., 7(5), 176182.

Sushil, K.; Badu, B.V. (2014). Separation of carboxylic acids from waste water via reactive extraction. www.researchgate.net.

Weekar, Y.; Xulfiqar, B.; Ahmed, I. (2017). Pharm a cognostic and phytochemical characteristics of Ainathus altissima (Mill.) swingle stem and root bark: A comparative study. Pharmacogn, J., 9(5), 668- 673. 